\title{
PENGARUH DIMENSI PELAYANAN DAN DIMENSI FASILITAS TERHADAP KEPUASAN MAHASISWA PADA UNIVERSITAS KANJURUHAN MALANG
}

\author{
Christea Frisdiantara \\ Andi Nu Graha
}

\begin{abstract}
Abstrak: Tujuan penelitian ini untuk (1) mengetahui pengaruh dimensi pelayanan terhadap tingkat kepuasan mahasiswa di Universitas Kanjuruhan Malang, (2) mengetahui pengaruh dimensi fasilitas terhadap tingkat kepuasan mahasiswa di Universitas Kanjuruhan Malang, (3) mengetahui pengaruh dimensi pelayanan dan dimensi fasilitas terhadap tingkat kepuasan mahasiswa di Universitas Kanjuruhan Malang. Penelitian ini merupakan penelitian penjelasan (explanatory research), untuk menguji hipotesis antar variabel dan berpusat pada penjelasan hubungan hubungan antar variabel; hubungan tersebut adalah interdependency, yaitu bertujuan mendeteksi ketergantungan antar satu variabel dengan variabel lainnya. Peneliti mengambil sampel sebesar 360 orang. Pengambilan sampel dilakukan dengan menggunakan teknik proportional stratified random sampling. Teknik pengumpulan data menggunakan kuesioner dan studi pustaka. Variabel dalam penelitian ini ada 3 (tiga) yaitu demensi pelayanan, dimensi fasilitas, dan kepuasan mahasiswa. Teknik analisis data menggunakan deskriptif dan analisis regresi berganda. Temuan penelitian ini adalah variabel dimensi kualitas pelayanan berpengaruh terhadap kepuasan mahasiswa, variabel dimensi fasilitas berpengaruh terhadap kepuasan mahasiswa, dan variabel kualitas pelayanan dan fasilitas secara simultan berpengaruh signifikan terhadap kepuasan mahasiswa.
\end{abstract}

Kata kunci : Dimensi Pelayanan, Dimensi Fasilitas, dan Kepuasan

\section{PENDAHULUAN}

Perguruan tinggi merupakan salah satu penyedia jasa, oleh karena itu, perguruan tinggi harus mampu memberikan pelayanan yang terbaik bagi konsumennya. Kondisi persaingan yang semakin ketat dalam bidang pendidikan saat ini, memaksa setiap perguruan tinggi ataupun penyelenggara pendidikan tinggi harus memberikan pelayanan yang terbaik serta berbeda dengan para saingan. Universitas Kanjuruhan Malang merupakan salah satu perguruan tinggi swasta yang berasal dari perubahan IKIP menjadi Universitas. Universitas Kanjuruhan Malang harus bisa memberikan pelayanan yang optimal kepada seluruh mahasiswa, untuk

Christea Frisdiantara, Dosen Prodi Akuntansi Fakultas Ekonomi Universitas Kanjuruhan Malang

Andi Nu Graha, Dosen Prodi Manajemen Fakultas Ekonomi Universitas Kanjuruhan Malang 
itu perlu meningkatkan kualitas pelayanan yang mampu diberikan kepada semua pihak yang berkepentingan.

Kebutuhan mahasiswa akan pelayanan dan fasilitas yang diberikan Universitas Kanjuruhan Malang selalu meningkat baik dari segi kualitas maupun kuantitas, hal ini seiring dengan perkembangan dan kemajuan jaman, dampaknya adanya perubahan perilaku mahasiswa dalam menentukan tempat memilih yang mereka anggap paling sesuai dan benar-benar dapat memenuhi kebutuhan dan keinginan mereka dalam menentukan pendidikan tinggi.

Semakin meningkatnya perkembangan Universitas Kanjuruhan Malang akan memberikan banyak alternatif kepada mahasiswa sebagai konsumen untuk memilih yang sesuai dengan kebutuhan dan kemampuan financial mereka. Hal ini harus diimbangi oleh pengambil kebijakan di Universitas Kanjuruhan Malang untuk berusaha menarik mahasiswa (konsumen) agar berminat masuk ke Universitas Kanjuruhan Malang. Pengambil kebijakan harus cepat tanggap dan segera menyesuaikan akan perubahan selera dan kemampuan konsumen. Meningkatnya kebutuhan akan pelayanan dan fasilitas, merupakan peluang bagi Universitas Kanjuruhan Malang untuk mendapatkan hasil yang menguntungkan bagi kelangsungan hidup Universitas dengan memberikan beragam pelayanan. Pelayanan dan fasilitas dapat berjalan dengan baik apabila ditunjang dengan manajemen yang profesional dari Universitas Kanjuruhan Malang.

\section{TINJAUAN PUSTAKA}

Penelitian terdahulu yang pernah dilakukan adalah penelitian tentang penilaian kualitas jasa pada sekolah bisnis yang dilakukan oleh Pariseau dan Mc Daniel (1997), penelitian ini dilakukan pada dua universitas di daerah North-East Region USA. Studi ini membandingkan antara harapan dan persepsi mahasiswa terhadap kualitas pelayanan yang diberikan oleh sekolah bisnis, yang meliputi pelayanan dosen, materi yang diberikan dan pelayanan non akademik. Dalam penelitian ini digunakan lima variabel seperti yang dikemukakan oleh Parasuraman yaitu variabel tangibles, reliability, empathy, responsiveness dan assurance, temuan penelitian ini menunjukan bahwa mahasiswa menilai bahwa sekolah bisnis harus memiliki tingkat assurance/jaminan yang tinggi kemudian baru diikuti oleh variabel responsiveness, hal ini juga telah sesuai dengan persepsi manajemen sekolah bisnis.

Lee et.all (2000) juga telah melakukan penelitian yang sama namun pada objek yang berbeda yaitu pada perusahaan jasa hiburan, kursus aerobik dan perusahaan jasa investasi, Lee menemukan bahwa variabel tangibility merupakan faktor yang penting pada industri berbasis peralatan dan responsiveness pada industri berbasis manusia. Penelitian lain yang dilakukan oleh Sureshchandar (2002) menemukan adanya hubungan yang sangat erat antara kualitas pelayanan dengan tingkat kepuasan pelanggan, semakin baik kualitas pelayanan maka besar kemungkinan konsumen akan semakin puas. Kelsey dan Bond (2001) juga menggunakan dimensi kualitas pelayanan sebagai fator penentu kepuasan konsumen dalam sebuah Academic Centre of Excellence. 


\section{Kepuasan Konsumen}

Menurut Kotler, kepuasan adalah tingkat perasaan seseorang setelah membandingkan kinerja atau hasil yang dia rasakan dibandingkan dengan harapannya (Kotler dkk, 2000 : 52). Sedangkan Tse dan Wilton (1988) dalam Lupiyoadi (2004:349) kepuasan atau ketidakpuasan pelanggan adalah respon pelanggan terhadap evaluasi ketidaksesuaian (disconfirmation) yang dirasakan antara harapan sebelumnya dan kinerja aktual produk yang dirasakan setelah pemakaiannya.

Wilkie (1990) mendefinisikannya sebagai suatu tanggapan emosional pada evaluasi terhadap pengalaman konsumsi suatu produk atau jasa. Engel, et al (1990) menyatakan bahwa kepuasan pelanggan merupakan evaluasi purna beli dimana alternatif yang dipilih sekurang-kurangnya sama atau melampaui harapan pelanggan, sedangkan ketidakpuasan timbul apabila hasil (outcome) tidak memenuhi harapan (Tjiptono, 2004 : 349) . Kepuasan pelanggan terhadap suatu produk ataupun jasa, sebenarnya sesuatu yang sulit untuk didapat jika perusahaan jasa atau industri tersebut tidak benar-benar mengerti apa yang diharapkan oleh konsumen. Untuk produk atau layanan dengan kualitas yang sama, dapat memberikan tingkat kepuasan yang berbeda-beda bagi konsumen yang berbeda. Oleh karena itu, suatu perusahaan harus selalu memperhatikan kualitas produk maupun pelayanan yang diberikan kepada konsumen.

Kepuasan pelanggan merupakan respons pelanggan terhadap ketidaksesuaian antara tingkat kepentingan sebelumnya dan kinerja aktual yang dirasakannya setelah pemakaian (Rangkuti, 2002:30). Kepuasan pelanggan dipengaruhi oleh persepsi kualitas jasa, kualitas produk, harga dan faktor-faktor yang bersifat pribadi serta yang bersifat situasi sesaat.

Kepuasan pelanggan merupakan respons pelanggan terhadap ketidaksesuaian antara tingkat kepentingan sebelumnya dan kinerja aktual yang dirasakannya setelah pemakaian (Rangkuti, 2002). Kepuasan pelanggan dipengaruhi oleh persepsi kualitas jasa, kualitas produk, harga dan faktorfaktor yang bersifat pribadi serta yang bersifat situasi sesaat. Salah satu faktor yang menentukan kepuasan pelanggan adalah persepsi pelanggan mengenai kualitas jasa yang berfokus pada lima dimensi kualitas jasa, yaitu: bukti fisik (tangibles), keandalan (reliability), daya tanggap (responsiveness), jaminan (assurance), empati (empathy).

Kepuasan pelanggan secara keseluruhan mempunyai tiga dimensi, yaitu kualitas yang dirasakan, nilai yang dirasakan, dan harapan pelanggan. Kualitas yang dirasakan secara langsung mempunyai efek positif terhadap kepuasan pelanggan secara keseluruhan. Kepuasan pelanggan secara keseluruhan akan berpengaruh negatif pada komplain pelanggan dan berpengaruh positif pada kesetiaan atau loyalitas pelanggan.

\section{Kualitas Pelayanan}

Modernitas dengan kemajuan teknologi akan mengakibatkan persaingan yang sangat ketat untuk memperoleh dan mempertahankan pelanggan. Kualitas pelayanan menjadi suatu keharusan yang harus dilakukan perusahaan supaya mampu bertahan dan tetap mendapat kepercayaan pelanggan. Pola konsumsi dan gaya hidup pelanggan menuntut perusahaan mampu memberikan pelayanan yang berkualitas. Keberhasilan perusahaan dalam memberikan pelayanan yang 
berkualitas dapat ditentukan dengan pendekatan service quality yang telah dikembangkan oleh Parasuraman, Berry dan Zenthaml (dalam Lupiyoadi,2006:181).

Service Quality adalah seberapa jauh perbedaan antara harapan dan kenyataan para pelanggan atas layanan yang mereka terima. Service Quality dapat diketahui dengan cara membandingkan persepsi pelanggan atas layanan yang benarbenar mereka terima dengan layanan sesungguhnya yang mereka harapkan. Kualitas pelayanan menjadi hal utama yang diperhatikan serius oleh perusahaan, yang melibatkan seluruh sumber daya yang dimiliki perusahaan.

Definisi mutu jasa berpusat pada pemenuhan kebutuhan dan keinginan pelanggan serta ketepatan penyampaian untuk mengimbangi harapan pelanggan. Menurut Wyckof (dalam Wisnalmawati, 2005:155) kualitas jasa adalah tingkat keunggulan yang diharapkan dan pengendalian atas tingkat keunggulan untuk memenuhi keinginan pelanggan. Apabila jasa yang diterima sesuai dengan yang diharapkan, maka kualitas jasa dipersepsikan baik dan memuaskan. Jika jasa yang diterima melampaui harapan pelanggan, maka kualitas jasa dipersepsikan ideal.

Sebaliknya jika jasa yang diterima lebih rendah dari pada yang diharapkan, maka kualitas jasa dianggap buruk (Tjiptono, 2005:121). Mengacu pada pengertian kualitas layanan tersebut maka konsep kualitas layanan adalah suatu daya tanggap dan realitas dari jasa yang diberikan perusahaan. Kualitas pelayanan harus dimulai dari kebutuhan pelanggan dan berakhir pada persepsi pelanggan (Kotler, 1997) dalam Wisnalmawati (2005:156). Hal ini berarti bahwa kualitas yang baik bukanlah berdasarkan persepsi penyediaan jasa, melainkan berdasarkan persepsi pelanggan.

Kualitas layanan mengacu pada penilaian-penilaian pelanggan tentang inti pelayanan, yaitu si pemberi pelayanan itu sendiri atau keseluruhan organizáis pelayanan, sebagian besar masyarakat sekarang mulai menampakkan tuntutan terhadap pelayanan prima, mereka bukan lagi sekedar membutuhkan produk yang bermutu tetapi mereka lebih senang menikmati kenyamanan pelayanan (Roesanto, 2000) dalam Tasunar (2006:44). Oleh karena itu dalam merumuskan strategi dan program pelayanan, organisasi harus berorientasi pada kepentingan pelanggan dan sangat memperhatikan dimensi kualitasnya (Suratno dan Purnama, 2004:74).

\section{1). Dimensi Kualitas Layanan}

Sunarto (2003:244) mengidentifikasikan tujuh dimensi dasar dari kualitas yaitu:

a). Kinerja

Yaitu tingkat absolut kinerja barang atau jasa pada atribut kunci yang diidentifikasi para pelanggan.

b). Interaksi Pegawai

Yaitu seperti keramahan, sikap hormat, dan empati ditunjukkan oleh masyarakat yang memberikan jasa atau barang.

c). Keandalan

Yaitu konsistensi kinerja barang, jasa dan toko.

d). Daya Tahan

Yaitu rentan kehidupan produk dan kekuatan umum.

e). Ketepatan Waktu dan Kenyaman

Yaitu seberapa cepat produk diserahkan atau diperbaiki, seberapa cepat produk infomasi atau jasa diberikan. 
f). Estetika

Yaitu lebih pada penampilan fisik barang atau toko dan daya tarik penyajian jasa.

g). Kesadaran akan Merek

Yaitu dampak positif atau negatif tambahan atas kualitas yang tampak, yang mengenal merek atau nama toko atas evaluasi pelanggan.

Garvin dalam Tjiptono dan Chandra (2005:113) mengembangkan delapan dimensi kualitas, yaitu:

a). Kinerja (performance) yaitu mengenai karakteristik operasi pokok dari produk inti. Misalnya bentuk dan kemasan yang bagus akan lebih menarik pelanggan.

b). Ciri-ciri atau keistimewaan tambahan (features), yaitu karakteristik sekunder atau pelengkap.

c). Kehandalan (reability), yaitu kemungkinan kecil akan mengalami kerusakan atau gagal dipakai.

d). Kesesuaian dengan spesifikasi (conformance to specifications). Yaitu sejauh mana karakteristik desain dan operasi memenuhi standar-standar yang telah ditetapkan sebelumnya. Seperti halnya produk atau jasa yang diterima pelanggan harus sesuai bentuk sampai jenisnya dengan kesepakatan bersama.

e). Daya tahan (durability), berkaitan dengan berapa lama produk tersebut dapat terus digunakan. Biasanya pelanggan akan merasa puas bila produk yang dibeli tidak pernah rusak.

f). Serviceability, meliputi kecepatan, kompetensi, kenyamanan, mudah direparasi; penanganan keluhan yang memuaskan.

g). Estetika, yaitu daya tarik produk terhadap panca indera. Misalnya kemasan produk dengan warna-warna cerah, kondisi gedung dan lain sebagainya.

h). Kualitas yang dipersepsikan (perceived quality), yaitu citra dan reputasi produk serta tanggung jawab perusahaan terhadapnya. Sebagai contoh merek yang lebih dikenal masyarakat (brand image) akan lebih dipercaya dari pada merek yang masih baru dan belum dikenal.

\section{Dimensi Fasilitas}

Fasilitas merupakan segala sesuatu yang memudahkan konsumen dalam menggunakan jasa perusahaan tersebut. Fasilitas adalah sumberdaya fisik yang ada dalam sebelum suatu jasa dapat ditawarkan kepada konsumen (Tjiptono,1997).

Raharjani (2005) menyatakan bahwa apabila suatu perusahaan jasa mempunyai fasilitas yang memadai sehinggga dapat memudahkan konsumen dalam menggunakan jasanya dan membuat nyaman konsumen dalam menggunakan jasanya tersebut tersebut maka akan dapat mempengaruhi konsumen dalam melakukan pembelian jasa. Selain itu perusahaan yang memberikan suasana menyenangkan dengan desain fasilitas yang menarik akan mempengaruhi konsumen dalam melakukan pembelian.

Menurut Mauling (2006) fasilitas adalah prasarana atau wahana untuk melakukan atau mempermudah sesuatu. Fasilitas bisa pula dianggap sebagai suatu alat. Fasilitas biasanya dihubungkan dalam pemenuhan suatu prasarana umum yang terdapat dalam suatu perusahaan atau organisasi tertantu. (http://www.geocities.com) 
Menurut Wahyuningrum (2004: 4), menyatakan bahwa fasilitas "segala sesuatu yang dapat memudahkan dan melancarkan pelaksanaan suatu usaha". Berdasarkan pengertian di atas, dapat disimpulkan bahwa fasilitas merupakan sarana dan prasarana yang dibutuhkan dalam melakukan atau memperlancar suatu kegiatan. Wahyuningrum (2004: 5), juga membedakan fasilitas menjadi 2 bagian yaitu:

1. Fasilitas fisik adalah segala sesuatu yang berupa benda atau yang dapat dibedakan, yang mempunyai peran dapat memudahkan dan melancarkan suatu usaha.

2. Fasilitas uang adalah segala sesuatu yang dapat memberi kemudahan suatu kegiatan sebagai akibat dari "nilai uang".

Kemudian sarana dilihat dari fungsinya atau perananya dapat dibedakan menjadi: alat pelajaran, alat peraga dan media pembelajaran. Prasarana pendidikan dapat diklasifikasikan menjadi dua macam. Pertama, prasarana yang secara langsung digunakan untuk proses belajar mengajar, seperti ruang teori, ruang perpustakaan, ruang praktek ketrampilan, dan ruang laboratorium. Kedua, pasarana yang keberandaanya tidak digunakan untuk proses belajar mengajar, tetapi secara langsung sangat menunjang terjadinya proses belajar mengajar. Contoh dari prasarana yang kedua ini adalah ruang kantor, ruang kepala sekolah, ruang guru, kamar kecil, dan kantin sekolah.

Menurut Bafadal (2003: 2), sarana pendidikan adalah "semua perangkatan peralatan, bahan dan perabot yang secara langsung digunakan dalam proses pendidikan di sekolah". Wahyuningrum (2004: 5), berpendapat bahwa sarana pendidikan adalah "segala fasilitas yang diperlukan dalam proses pembelajaran, yang dapat meliputi barang bergerak maupun barang tidak bergerak agar tujuan pendidikan tercapai".

Dapat disimpulkan dari beberapa pendapat di atas, bahwa sarana pendidikan adalah segala fasilitas bisa berupa peralatan, bahan dan perabot yang langsung dipergunakan dalam proses belajar di sekolah. Dalam konteks pendidikan, sarana dan prasarana adalah semua fasilitas yang diperlukan dalam proses belajar mengajar baik yang bergerak maupun tidak bergerak, yang secara langsung maupun tidak langsung dapat berpengarauh terhadap tujuan pendidikan.

Bafadal (2004: 12), mengemukakan bahwa Prasarana pendidikan dapat diartikan sebagai perangkat yang menunjang keberlangsungan sebuah proses pendidikan, sedangkan definisi dari prasarana adalah "semua perangkat kelengkapan dasar yang secara tidak langsung menunjang pelaksanaan proses pendidikan sekolah".

Menurut Riduone (2009), prasarana pendidikan dapat diartikan sebagai perangkat penunjang utama suatu proses atau usaha pendidikan agar tujuan pendidikan tercapai. Dari pendapat di atas dapat diambil kesimpulan bahwa prasarana pendidikan adalah perangkat yang menunjang keberlangsunan proses pendidikan agar tujuan pendidikan tercapai. 


\section{METODE}

\section{Rancangan Penelitian}

Penelitian ini merupakan penelitian penjelasan (explanatory research), untuk menguji hipotesis antar variabel dan berpusat pada penjelasan hubungan hubungan antar variabel; hubungan tersebut adalah interdependency, yaitu bertujuan mendeteksi ketergantungan antar satu variabel dengan variabel lainnya.

\section{Populasi dan Sampel}

Populasi dari penelitian ini adalah mahasiswa program studi di lingkungan Universitas Kanjuruhan Malang yang terdaftar pada semester genap tahun akademik 2011/2012 yaitu berjumlah 6442 mahasiswa berdasarkan data dari Biro Administrasi Akademik (BAA, 2012). Peneliti mengambil sampel sebesar 360 orang, yang berasal dari 18 program studi setiap angkatan diambil perwakilannya 5 orang, saat ini tercatat di BAA ada empat angkatan yaitu 2011, 2010, 2009, dan 2008. Pengambilan sampel dilakukan dengan menggunakan teknik proportional stratified random sampling.

\section{Variabel Dalam Penelitian}

Untuk mengetahui secara rinci tentang variabel-variabel dan indikatorindikatornya dalam penelitian ini dapat dijelaskan sebagai berikut :

Tabel 1

Variabel dan Indikator

\begin{tabular}{|l|l|}
\hline \multicolumn{1}{|c|}{ Variabel } & \multicolumn{1}{c|}{ Indikator } \\
\hline \multirow{4}{*}{ Kualitas Pelayanan (X1) } & Kinerja \\
\cline { 2 - 2 } & Interaksi Pegawai \\
\cline { 2 - 2 } & Ketepatan Waktu \\
\cline { 2 - 2 } & Kenyaman \\
\cline { 2 - 2 } Fasilitas (X2) & Estetika \\
& Fasilitas Akademik \\
\cline { 2 - 2 } & Fasilitas Non Akademik \\
\cline { 2 - 2 } & Fasilitas Penunjang \\
\cline { 2 - 2 } & Fasilitas Publik \\
\cline { 2 - 2 } & Sarana Rekreatif \\
\hline & Kualitas yang dirasakan \\
\cline { 2 - 2 } & Nilai yang dirasakan \\
\cline { 2 - 2 } & Harapan pelanggan \\
\hline
\end{tabular}

\section{Teknik pengumpulan data dan Analisis Data}

Metode pengumpulan data penelitian ini menggunakan Kuesioner dan Studi Pustaka. Kuesioner dalam penelitian ini menggunakan pertanyaan tertutup. Analisis data menggunakan Regresi Linear Berganda. Uji hipotesis, Uji t dan Uji F. 


\section{PEMBAHASAN}

Penelitian ini bertujuan untuk mengetahui pengaruh secara simultan maupun parsial dari kualitas pelayanan dan fasilitas terhadap kepuasan mahasiswa. Data hasil penelitian memberikan dukungan bahwa kedua variabel ini secara simultan berpengaruh signifikan terhadap kepuasan mahasiswa.

\section{Pengaruh Kualitas Pelayanan Terhadap Kepuasan Mahasiswa}

Hasil analisis regresi membuktikan bahwa secara parsial terdapat pengaruh signifikan dari kualitas pelayanan terhadap kepuasan mahasiswa. Kepuasan mahasiswa dapat dijelaskan oleh pemberian kualitas pelayanan yang memadai. Hasil ini sejalan dengan penelitian yang dilakukan oleh Sureshchandar (2002) dan Kelsey dan Bond (2001). Secara empiris komponen kualitas pelayanan terdiri dari atas kinerja, interaksi pegawai, ketepatan waktu, kenyamanan dan estetika. Seluruh komponen kualitas pelayanan telah dinilai secara baik oleh mahasiswa terutama dari unsur ketepatan waktu dan kenyamanan. Sedangkan kelemahan ada pada persoalan estetika, terutama dari sisi penampilan dan cara berkomunikasi.

Hasil paparan secara deskriptif tampak bahwa kualitas pelayanan yang diberikan kepada mahasiswa sebenarnya sudah termasuk dalam klasifikasi cukup baik. Akan tetapi secara khusus di masing-masing indikator memiliki beberapa kelemahan harus dilakukan perbaikan untuk meningkatkan kualitas pelayanan. Peta kelemahan akan diulas berbasis proporsi jawaban yang mengarah pada tidak baik terbesar dalam pada salah satu item dalam indikator. Pada kualitas pelayanan kelemahan-kelemahan tersebut antara lain: kejujuran, keramahan, keberadaan karyawan saat jam kerja, pemberian rasa aman dan kerapihan dalam tampilan.

Peningkatan kualitas pelayanan bisa dilakukan secara internal dan eksternal. Evaluasi internal lebih mengarah pada individu karyawan, sedangkan evaluasi eksternal lebih banyak bersumber dari terciptanya keadaan atau lingkungan kerja yang memberikan dukungan terhadap meningkatnya kualitas pelayanan seperti sarana prasarana kerja dan rekan kerja.

Setiap karyawan seharusnya memahami akan tugas pokoknya untuk dapat memberikan pelayanan prima kepada mahasiswa. Kemampunan kerja dalam arti kompetensi baik dalam hal mengenal proses kerja dan keinginan untuk memberikan layanan terbaik akan terbentuk baik apabila karyawan mempunyai kecerdasan emosional yang memadai. Kemampuan kognitif karyawan untukmdapat mengenal tugas pelayanan secara sempurna adalah cara terbaik untuk meningkatkan kinerja karyawan.

Kualitas pelayanan merupakan komponen penting pada setiap mahasiswa untuk menjadi puas menjalani perkuliahn. Kualitas pelayanan lebih diarahkan pada pemenuhan jangka pendek untuk tugas-tugas operasional. Output yang diharapkan dari kualitas pelayanan adalah terciptanya tingkat kepuasan yang tinggi bagi mahasiswa pada banyak aspek baik akademik maupun non akademik.

Dalam memenuhi kebutuhan akan sumber daya manusia yang berkualitas, salah satunya adalah melalui ketersediaan karyawan yang mampu memberikan kualitas pelayanan yang cukup. Kualitas pelayanan bagi mahasiswa, bukan saja semata-mata untuk sekedar memenuhi kebutuhan organisasi melainkan juga untuk memenuhi kebutuhan mahasiswa yang merasakan arti penting dari kualitas pelayanan. 
Oleh karena itu apabila karyawan telah dapat memecahkan permasalahan pemberian kualitas layanan yang prima, maka diharapkan yang bersangkutan akan dapat menumbuhkan tingkat kepuasan mahasiwa yang baik. Dari analisis tersebut menjadi dasar bahwa adanya pengaruh antara kualitas pelayanan dengan kepuasan mahasiswa. Namun demikian untuk memperoleh hasil yang maksimal dari kualitas pelayanan dalam meningkatkan kepuasan mahasiswa, maka perlu mengambil langkah yang efektif. Mahasiswa harus dipandang sebagai pasar, sehingga bila dikaitkan dengan saran Tjiptono (2002:56), maka ada tiga kunci memberikan pelayanan yang unggul bagi mahasiswa antara lain:

1. Kemampuan memahami kebutuhan dan keinginan mahasiswa.

2. Pengembangan data base yang lebih akurat dari perguruan tinggi pesaing.

3. Pemanfaatan informasi-informasi yang diperoleh dari riset pasar dalam pengembangan pemasaran.

Kebutuhan mahasiswa akan pelayanan dan fasilitas yang diberikan Universitas Kanjuruhan Malang selalu meningkat baik dari segi kualitas maupun kuantitas, hal ini seiring dengan perkembangan dan kemajuan jaman, dampaknya adanya perubahan perilaku mahasiswa dalam menentukan tempat memilih yang mereka anggap paling sesuai dan benar-benar dapat memenuhi kebutuhan dan keinginan mereka dalam menentukan pendidikan tinggi.

Hal yang perlu diperhatikan dalam memberikan pelayanan adalah mendengar suara konsumen, hal ini berarti intitusi harus melakukan interaksi dengan konsumen dalam hal ini mahasiswa dengan maksud untuk memperoleh umpan balik (feed back) berapa tanggapan konsumen tentang sarana dan prasarana yang berhubungan dengan pelayanan yang diberikan. Hal ini dapat kita contohkan melalui penyediaan sarana dan prasarana di Universitas Kanjuruhan Malang, peranan sarana dan prasaran yang semakin besar. Hal ini terlihat dengan semakin bertambahnya jumlah mahasiswa. Pelayanan penyediaan sarana dan prasarana merupakan salah satu fasilitas untuk memenuhi kebutuhan mahasiswa.

Dewasa ini perhatian terhadap kepuasan maupun ketidakpuasan mahasiswa telah semakin besar karena pada dasarnya tujuan dari suatu perguruan tinggi adalah untuk menciptakan rasa puas dalam menyelesaikan perkuliahan pada mahasiswa. Semakin tinggi tingkat kepuasan mahasiswa, maka akan mendatangkan keuntungan yang semakin besar bagi perguruan tinggi, karena mahasiswa akan melakukan promosi secara tidak langsung terhadap konsumen yang berpotensi untuk menciptakan peluang pembelian terhadap produk perusahaan. Hal ini tidak akan terjadi, apabila tingkat kepuasan yang dirasakan mahasiswa kecil. Bahkan akan terdapat kemungkinan bahwa hal ini akan menimblkan swicthing choice ke perguruan tinggi lain.

Kualitas layanan dari perguruan tinggi akan memiliki hubungan yang erat dengan kepuasan mahasiswa. Kualitas memberikan suatu dorongan kepada mahasiswa untuk menjalin ikatan hubungan yang kuat dengan perguruan tingginya. Dalam jangka panjang ikatan seperti ini memungkinkan perguruan tinggi untuk memahami dengan seksama harapan mahasiswa serta kebutuhan mereka. Dengan demikian, perguruan tinggi dapat meningkatkan kepuasan mahasiswa dengan cara memaksimumkan pengalaman yang menyenangkan dan meminimumkan pengalaman yang kurang menyenangkan (Tjiptono, 1996). 


\section{Pengaruh Fasilitas Terhadap Kepuasan mahasiswa}

Hasil analisis regresi membuktikan bahwa secara parsial terdapat pengaruh signifikan dari fasilitas terhadap kepuasan mahasiswa. Kepuasan mahasiswa yang dapat dijelaskan oleh fasilitas mahasiswa. Hasil ini sejalan dengan penelitian yang dilakukan oleh Pariseau dan Mc Daniel (1997) serta Lee et.all (2000). Secara empiris komponen fasilitas terdiri atas fasilitas akademik, non akademik, penunjang, fasilitas publik dan sarana rekreatif. Seluruh komponen fasilitas telah dinilai baik oleh responden terutama dari fasilitas akademik, sarana penunjang dan sarana rekreatif. Berdasarkan harga rata-rata pada masing-masing indikator, fasilitas non akademik dan fasilitas publik dinilai kurang dibandingkan dengan fasilitas lain yang meliputi fasilitas kegiatan kemahasiswaan, koperasi dan masjid.

Rutinitas pemberian layanan bagi mahasiswa mempunyai berbagai masalah dan tantangan, misalnya persaingan yang ketat, tuntutan tugas, suasana belajar yang tidak nyaman dan masalah hubungan dengan orang lain. Kondisi riil berdasarkan hasil wawancara di lapangan terlihat masih banyak pelayanan dan fasilitas yang diberikan Universitas Kanjuruhan Malang dinilai sebagian mahasiswa belum maksimal. Hal ini terlihat pada prosedur pengurusan akademis di program studi (PRODI), pelayanan dosen yang masih dinilai kurang, serta kurangnya sarana dan prasarana pendukung pembelajaran dan sarana umum seperti fasilitas lahan parkir, hot spot, smoking area, open axis area, loker penitipan di masjid, dll.

Fasilitas yang baik akan membuat seorang mahasiswa akan merasakan kepuasan yang lebih baik. Prestasi mahasiswa tidak hanya didukung oleh faktor intelektualnya saja tetapi juga ditentukan ketersediaan fasilitas dalam kampus. Salah satu faktor yang mempengaruhi prestasi mahasiswa adalah fasilitas sebagai pengimbang dari kualitas pelayanan. Kedua hal ini harus tersus dikelola dengan baik, sehingga akan membantu perguruan tinggi untuk mencapai tujuan yaitu pelayanan prima bagi customer di universitas yaitu mahasiswa dan dosen. Fasilitas digunakan sebagai salah satu cara untuk memotivasi dan meningkatkan prestasi kerja yang diinginkan.

Dalam suatu organisasi fasilitas yang dimiliki mahasiswa diharapkan akan menjadikan setiap pekerjaan menjadi efektif dan efisien. Fasilitas yang tinggi bagi mahasiswa akan dapat membantu dirinya saat belajar menjadi lebih tenang dan mengkonsentrasikan seluruh pikirannya untuk menyelesaikan pekerjaan yang menjadi tanggung jawabnya. Bila hal demikian dapat terealisasi, maka perguruan tinggi akan dapat mencapai tujuannya. Adanya pengaruh antara fasilitas terhadap kepuasan kerja juga bahwa harus diwaspadai apabila terjadi pada keadaan yang sebaliknya. Fasilitas yang tidak memadai akan dapat menghambat prestasi mahasiswa.

Fasilitas merupakan faktor yang penting dalam menentukan kepuasan mahasiswa. Faktor fasilitas untuk memilih suatu produk khususnya produk jasa, dimana fasilitas yang lengkap dan memadai yang diberikan akan membuat mahasiswa merasa puas terhadap jasa yang dipakainya. Terdapat banyaknya fasilitas penyediaan sarana dan prasarana mengakibatkan mahasiswa dihadapkan pada banyaknya pilihan jasa yang di tawarkan. Karakteristik fasilitas pelayanan yang relatif padat modal dan praktis tidak bisa dipindah-pindah, menuntut adanya pola 
pengembangan usaha yang bertahap, sistematis, rasional, serta dikelola secara efektif, efisien, dan akuntabel.

Fasilitas yang baik maka dapat membentuk persepsi di mata pelanggan (Tjiptono, 2006). Pada konsteks perguruan tinggi sebagai sebuah organisasi penyedia jasa, persepsi yang terbentuk dari interaksi antara mahasiswa dengan fasilitas berpengaruh terhadap kepuasan akan kualitas jasa di mata mahasiswa. Pada perusahaan jasa mempunyai fasilitas yang memadai sehinggga dapat memudahkan konsumen dalam menggunakan jasanya dan membuat nyaman konsumen dalam menggunakan jasanya tersebut tersebut maka akan dapat mempengaruhi konsumen dalam melakukan pembelian jasa (Raharjani (2005). Selain itu perusahaan yang memberikan suasana menyenangkan dengan desain fasilitas yang menarik akan mempengaruhi konsumen dalam melakukan pembelian. Fasilitas yang disediakan oleh universitas Kanjuruan telah memadai pada banyak aspek, dan perlu ditingkatkan pada beberapa fasilitas tertentu seperti koperasi dan masjid.

Fasilitas adalah prasarana atau wahana untuk melakukan atau mempermudah sesuatu (Mauling, 2006 dan Wahyuningrum (2004). Fasilitas merupakan sarana dan prasarana yang dibutuhkan dalam melakukan atau memperlancar suatu kegiatan perkuliahan mahasiswa. Fasilitas yang disediakan dilihat dari fungsinya atau perananya dapat dibedakan menjadi: alat pelajaran, alat peraga dan media pembelajaran. Prasarana pendidikan dapat diklasifikasikan menjadi dua macam. Pertama, prasarana yang secara langsung digunakan untuk proses belajar mengajar, seperti ruang teori, ruang perpustakaan, ruang praktek ketrampilan, dan ruang laboratorium. Kedua, pasarana yang keberandaanya tidak digunakan untuk proses belajar mengajar, tetapi secara langsung sangat menunjang terjadinya proses belajar mengajar. Fasilitas pendidikan adalah perangkat yang menunjang keberlangsungan sebuah proses pendidikan, yang secara tidak langsung menunjang pelaksanaan proses pendidikan di lembaga pendidikan (Ibrahim Bafadal, 2004 dan Riduone, 2009).

\section{KESIMPULAN}

Berdasarkan hasil analisis dan pembahasan pada bab sebelumnya, maka diperoleh kesimpulan sebagai berikut :

1. Hasil analisis regresi membuktikan bahwa secara parsial terdapat pengaruh signifikan dari kualitas pelayanan terhadap kepuasan mahasiswa. Hasil paparan secara deskriptif tampak bahwa kualitas pelayanan yang diberikan kepada mahasiswa sebenarnya sudah termasuk dalam klasifikasi cukup baik. Akan tetapi secara khusus di masing-masing indikator memiliki beberapa kelemahan harus dilakukan perbaikan untuk meningkatkan kualitas pelayanan. Peta kelemahan akan diulas berbasis proporsi jawaban yang mengarah pada tidak baik terbesar dalam pada salah satu item dalam indikator. Pada kualitas pelayanan kelemahan-kelemahan tersebut antara lain: kejujuran, keramahan, keberadaan karyawan saat jam kerja, pemberian rasa aman dan kerapihan dalam tampilan.

2. Hasil analisis regresi membuktikan bahwa secara parsial terdapat pengaruh signifikan dari fasilitas terhadap kepuasan mahasiswa. Kepuasan mahasiswa yang dapat dijelaskan oleh fasilitas mahasiswa. Secara empiris komponen 
fasilitas terdiri atas fasilitas akademik, non akademik, penunjang, fasilitas publik dan sarana rekreatif. Seluruh komponen fasilitas telah dinilai baik oleh responden terutama dari fasilitas akademik, sarana penunjang dan sarana rekreatif. Berdasarkan harga rata-rata pada masing-masing indikator, fasilitas non akademik dan fasilitas publik dinilai kurang dibandingkan dengan fasilitas lain yang meliputi fasilitas kegiatan kemahasiswaan, koperasi dan masjid. Rutinitas pemberian layanan bagi mahasiswa mempunyai berbagai masalah dan tantangan, misalnya persaingan yang ketat, tuntutan tugas, suasana belajar yang tidak nyaman dan masalah hubungan dengan orang lain.

3. Hasil analisis regresi membuktikan bahwa kualitas pelayanan dan fasilitas secara simultan berpengaruh signifikan pada kepuasan mahasiswa. Secara umum dengan hasil temuan penelitian ini bahwa pihak kampus dapat mengetahui dan mengidentifikasi hal-hal yang menjadi kebutuhan dan keinginan mahasiswa

\section{SARAN}

1. Kinerja setiap unit pelayanan harus selalu ditanamkan sikap jujur kepada mahasiswa.

2. Interaksi karyawan setiap unit pelayanan perlu ditingkatkan sikap ramah kepada mahasiswa.

3. Ketepatan waktu setiap unit pelayanan perlu ditingkatkan keberadaannya ada saat di jam kerja.

4. Kenyamanan setiap unit pelayanan perlu ditingkatkan pemberian rasa aman kepada mahasiswa.

5. Estetika setiap unit pelayanan perlu selalu menjaga kerapian dalam berpakaian.

6. Fasilitas akademik berupa perpustakaan perlu ditingkatkan.

7. Fasilitas non akademik berupa kegiatan kemahasiswaan (ORMAWA) perlu ditingkatkan.

8. Fasilitas penunjang berupa aula pertemuan akademik perlu ditingkatkan.

9. Fasilitas publik berupa koperasi mahasiswa (KOPMA) perlu ditingkatkan.

10. Sarana rekreatif berupa panjat tembing perlu ditingkatkan.

11. Kepuasan berupa kualitas yang dirasakan setiap unit pelayanan perlu ditingkatkan mutu pelayanan akademik.

12. Kepuasan berupa nilai yang dirasakan setiap unit pelayanan perlu ditingkatan manfaat sarana dan prasaran serta manfaat pelayanan yang diberikan.

13. Kepuasan berupa harapan setiap unit pelayanan perlu ditingkatkan hubungan sikap dan perilaku yang baik setiap karyawan.

\section{DAFTAR PUSTAKA}

Bafadal, Ibrahim. (2003). Manajemen Perlengkapan Sekolah Teori dan Aplikasinya. Jakarta : Bumi Aksara.

Bafadal, Ibrahim. (2004). Manajemen Perlengkapan Sekolah Teori dan Aplikasinya. cet 2. Jakarta: Bumi Aksara. 
118 MODERNISASI, Volume 9, Nomor 2, Juni 2013

Engel, James F., Roger D. Blackwell, dan Paul W. Miniard., (1995), "Perilaku Konsumen”, Edisi Keenam, Jilid II, Binarupa Aksara, Jakarta.

Ghozali, Imam. 2005. Aplikasi Analisis Multivariate dengan Program SPSS. Semarang: Badan Penerbit Universitas Diponegoro.

Hair, JF. Jr, RE.Anderson. R.L. Tatham. W.C Black.1998. Multivariate Data Analysis, 5th ed, Pren-Hall Inc, Upper Saddle River

Kandampully, J and D. Suhartanto, (2000), Customer Loyalty in the Hotel Industry: The Role of Customer Satisfaction and Image, International Journal of Contemporary Hospitality Management, p. 346 - 351.

Kelsey, K.D. Bond, J.A, 2001, A Model for Meassuring Customer Satisfaction within An Academic Center of Excellence. Journal of Managing Service Quality. Vol. 11 No. 5. p. 359-367.

Kenny, David, 1997, Statistics For the Social and Behavioral Sciences. Little Brown and Company, Canada.

Kotler, Philip dan A.B Susanto. 2000. Manajemen Pemasaran Jasa Di Indonesia, Analisis Perencanaan, Implementasi dan pengendalian (Edisi pertama).Jakarta: Salemba Empat.

Lee, Hasik.Yongki Lee.Dongkeun Yoo.2000. The Determinants of Perceived Service Quality and Its Relationship with Satisfaction. Journal of Services Marketing. Vol 14. No. 3. p.217-231

Lupiyoadi, Rambat dan A. Hamdani. 2006. Manajemen Pemasaran Jasa. Jakarta: Salemba Empat.

Lupiyoadi, Rambat. 2004. Manajemen Pemasaran Jasa : Teori dan Pratek.Jakarta: PT Salemba Empat.

Moore, DS, 2007, The Basic Practice of Statistics, Edisi Keempat, Freeman and Company, New York.

Nasution, M. Nur. 2004. Manajemen Jasa Terpadu. Bogor: Ghalia Indonesia.

Parasuraman. V.A Zeithaml, Leonard L Berry.1998.SERVQUAL:A multiple-Item Scale for Measuring Consumer Perceptions of Service Quality. Journal of Retailing. Vol 64. No.1.

Pariseau, Susan E. McDaniel, J.R.1997. Assesing Service Quality in Schools of Business. International Journal of Quality \& Reliability Management. Vol. 14. No.3. p. 204-218 
Rangkuti, Freddy. 2002. Measuring Customer Satisfaction (cetakan ketiga). Jakarta, PT.Gramedia Pustaka Utama.

Riduone. (2009). Manajemen Sarana dan Prasarana Pendidikan Islam. (online) http://riduone co $\mathrm{nr}$ htm, diakses 5 Februari Pukul 5:00 Pm.

Sri Suratno F.G. dan Nursya' Bani Purnama. 2004. "Analisis Tingkat Kepuasan Wajib Pajak Terhadap Kualitas Layanan Kantor Pelayanan Pajak Yogyakarta Dua”. Sinergi Kajian Bisnis dan Manajemen, Vol. 7, No. 1, h. 69-87

Sugiyono. 2004. Metode Penelitian Bisnis. Bandung: CV. ALFABETA.

Sugiyono. 2007. Statistika Untuk Penelitian. Bandung: ALFABETA.

Sunarto. 2003. Perilaku Konsumen. Yogyakarta : AMUS Jogyakarta dan CV.Ngeksigondo Utama.

Sureshchandar, G.S. Chandrasekharan Rajendran. R.N Anantharaman, 2002. The Relationship Between Service Quality and Customer Satisfaction- a Factor Specific Approach. Journal of Services Marketing. Vol16. No. 4 p. $363-$ 379

Tasunar, Nanang. 2006. "Kualitas Layanan Sebagai Strategi Menciptakan Kepuasan pada Pangkalan Pendaratan Ikan (PPI) Morodemak". Jurnal Sains Pemasaran Indonesia, Vol. V, No. 1 Mei 2006, h. 41-62

Tjiptono, Fandy dan Gregorius Chandra. 2005. Service Quality Satisfaction. Yogyakarta : Penerbit Andi.

Tjiptono, Fandy. 1997. Strategi Pemasaran (Edisi II). Yogyakarta: Penerbit Andi.

Tjiptono, Fandy. 2000. Perspektif Manajemen dan Pemasaran Kontemporer. Yogyakarta: Penerbit Andi.

Tjiptono, Fandy. 2004. Pemasaran Jasa. Malang: Bayumedia.

Wahyuningrum. (2000). Buku Ajar Manajemen Fasilitas Pendidikan. Yogyakarta : FIP UNY

Wisnalmawati. 2005. Pengaruh Persepsi Dimensi Kualitas Layanan Terhadap Niat Pembelian Ulang. Jurnal Ekonomi dan Bisnis, No. 3 Jilid 10 2005, h. 153165 